\title{
MATRIK
}

Jurnal Manajemen dan Teknik Industri-Produksi

Journal homepage: http://www.journal.umg.ac.id/index.php/matriks

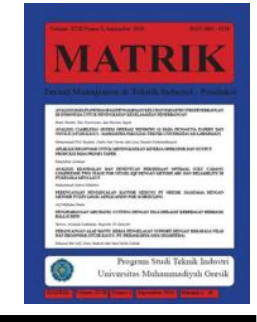

\section{Implementasi metode Failure Mode and Effect Analysis pada Industri di Asia - Kajian Literatur}

\section{Tri Aprianto ${ }^{1 *}$, Indra Setiawan ${ }^{2}$, Humiras Hardi Purba ${ }^{3}$}

Program Pascasarjana, Magister Teknik Industri, Universitas Mercu Buana Jakarta

Jl. Meruya Selatan No.1 Kembangan, Jakarta 11650, Jawa Barat, Indonesia aprianto5785@gmail.com

\begin{tabular}{|c|c|}
\hline INFO ARTIKEL & ABSTRAK \\
\hline $\begin{array}{l}\text { Jejak Artikel : } \\
\text { Upload artikel } \\
\text { O3 Desember } 2020 \\
\text { Revisi dari reviewer } \\
21 \text { Februari } 2020 \\
\text { Publish } \\
30 \text { Maret } 2021\end{array}$ & $\begin{array}{l}\text { Failure Mode Effect Analysis (FMEA) adalah suatu alat yang } \\
\text { secara sistematis mengidentifikasi akibat ataukonsekuensi dari kegagalan } \\
\text { sistem atau proses, serta mengurangi atau mengeliminasi peluang } \\
\text { terjadinya kegagalan. Tujuan dari makalah ini adalah untuk } \\
\text { mengidentifikasi mode kegagalan potensial dan dampaknya untuk } \\
\text { meningkatkan keandalan dan keamanan sistem yang kompleks. Selain itu } \\
\text { teknik ini juga berguna untuk mengumpulkan data yang dibutuhkan } \\
\text { untuk pengambilan keputusan dan pengendalian risiko. FMEA } \\
\text { merupakan sebuah alat yang diintegrasikan dengan banyak metode } \\
\text { seperti Quality Function Deployment (QFD), Root Cause Analysis (RCA), Six } \\
\text { Sigma, FTA, Fuzzy Kano, DEMATEL dan tujuh alat dasar kualitas untuk } \\
\text { mengatasi permasalahannya. Makalah ini melibatkan studi review dari } 30 \\
\text { makalah di kawasan Asia yang terkait dengan implementasi alat FMEA } \\
\text { di berbagai industri. Metodologi FMEA sekarang populer banyak } \\
\text { digunakan di berbagai industri termasuk di industri manufaktur untuk } \\
\text { mengembangkan produknya. Selain itu FMEA juga sering ditemukan } \\
\text { dalam analisis kegagalan di industri jasa, layanan makanan, konstruksi, } \\
\text { pertambangan, pertanian maupun di industri kesehatan. Makalah ini } \\
\text { memuat hasil dari berbagai aspek yang berbeda. Aspek itu meliputi fokus } \\
\text { industri, fokus jumlah distribusi menurut negara dan fokus tahun } \\
\text { publikasi. Makalah ini bermanfaat bagi semua jenis sektor industri untuk } \\
\text { menngidentifikasi mode kegagalan dan dampaknya serta untuk } \\
\text { pengendalian resiko. Makalah ini juga memberikan keuntungan bagi } \\
\text { peneliti selanjutnya untuk menambah wawasan dan referensi untuk studi } \\
\text { terkait alat FMEA }\end{array}$ \\
\hline
\end{tabular}




\section{Pendahuluan}

FMEA pertama kali diperkenalkan pada akhir 1940-an digunakan di bidang militer oleh Angkatan bersenjata AS. Pada saat itu FMEA digunakan untuk pengembangan roket untuk menghindari kesalahan dalam ukuran sampel kecil dari teknologi roket yang mahal. Meskipun awalnya dikembangkan oleh militer, metodologi FMEA sekarang banyak digunakan di berbagai industri termasuk manufaktur, jasa maupun kontruksi. FMEA memungkinkan tim untuk merancang kegagalan tersebut keluar dari sistem dengan sedikit usaha dan pengeluaran sumber daya, sehingga mengurangi waktu dan biaya pengembangan.

Dewasa ini sebuah perusahaan agar tetap kompetitif di pasar dan mendapatkan loyalitas pelanggan di produk, perusahaan harus memberikan banyak perhatian pada peningkatan kualitas yang berkelanjutan. Untuk menjaga kualitas produk dan layanan yang tinggi, perusahaan menerapkan sebuah metodologi khusus untuk mengatasinya. FMEA adalah pendekatan langkah demi langkah untuk mengevaluasi proses untuk mengidentifikasi semua kemungkinan kegagalan dan untuk menilai dampak relatif dari berbagai kegagalan untuk mengidentifikasi bagian-bagian dari proses yang memerlukan perubahan. Padahal, tujuan dari teknik ini yaitu a) untuk mengidentifikasi mode kegagalan dan efeknya; b) untuk menentukan tindakan korektif untuk menghilangkan atau mengurangi kemungkinan kegagalan c) pengembangan sistem pemeliharaan yang efisien untuk mengurangi terjadinya skenario potensial. Beberapa penelitian lain telah menyelidiki dan mencoba mengeksplorasi berbagai manfaat dan kegunaannya.

Menurut Stamatis [1], ada empat jenis FMEA, yaitu sistem, desain, proses, dan layanan. Sistem FMEA adalah analisis sistem tingkat tertinggi, yang terdiri dari berbagai subsistem. Design FMEA yang berfokus pada desain sebuah produk. Design FMEA akan menguji fungsi dari komponen, sub sistem dan sistem. Modus potensialnya dapat berupa kesalahan pemilihan jenis material, ketidaktepatan spesifikasi dan yang lainnya. Seharusnya analisis ini dilakukan sejak desain produk awal. Proses FMEA menekankan pada manufaktur atau proses perakitan yang berfokus pada kualitas produk yang dihasilkan. Proses FMEA akan menguji kemampuan proses yang akan digunakan untuk membuat komponen, sub sistem dan sistem. Modus pontensialnya dapat berupa kesalahan operator dalam merakit part, adanya variasi proses yang terlalu besar sehingga produk diluar batas spesifikasi yang telah ditetapkan serta faktor yang lainnya. Terakhir, layanan FMEA bertanggung jawab untuk menganalisis layanan sebelum mencapai ke pelanggan.

Ada beberapa alasan mengapa kita perlu menggunakan FMEA diantaranya lebih baik mencegah terjadinya kegagalan dari pada memperbaiki kegagalan, meningkatkan peluang kita untuk dapat mendeteksi terjadinya suatu kegagalan, mengindentifikasi penyebab kegagalan terbesar dan mengeliminasinya, mengurangi peluang terjadinya kegagalan dan membangun kualitas dari produk dan proses. FMEA akan sangat berguna sebagai suatu aktivitas "before the event". FMEA mempunyai keuntungan jika diterapkan dalam operasional perusahaan, keuntungan dalam penerapan teknik FMEA antara lain :

- Perbaikan mutu, reliability dan keselamatan dari produk dan proses.

- Meningkat daya saing penjualan dan kepuasan pelanggan

- Mengurangi biaya, waktu kerja dan resiko pemborosan/kerugian yang mungkin terjadi

- Peringatan dini sebelum masalah dan kesulitan terjadi

- Memfungsikan kerjasama team

- Menghilangkan masalah muncul dan terulang kembali

- Dapat dipergunakan sebagai masukan bagi perencanaan tindakan pencegahan.

Secara tradisional, FMEA digunakan untuk melakukan analisis risiko melalui Risk Priority Number (RPN) yaitu berasal dari kombinasi Occurrence (O), Severity (S) dan Detection (D). RPN akan melakukannya mengidentifikasi mode kegagalan kritis dari sistem, desain, proses dan latau layanan, dan memprioritaskannya tindakan.

- Tingkat Keparahan (Severity) 
Severity adalah penilaian terhadap keseriusan dari efek yang ditimbulkan dalam arti setiap kegagalan yang timbul akan dinilai seberapa besarkah tingkat keseriusannya. Terdapat hubungan secara langsung antara efek dan severity. Sebagai contoh, apabila efek yang terjadi adalah efek yang kritis, maka nilai severity pun akan tinggi. Dengan demikian, apabila efek yang terjadi bukan merupakan efek yang kritis, maka nilai severity pun akan sangat rendah

- Tingkat Kejadian (Occurance)

Occurance adalah kemungkinan bahwa penyebab tersebut akan terjadi dan menghasilkan bentuk kegagalan selama masa penggunaan produk. Occurance merupakan nilai rating yang disesuaikan dengan frekuensi yang diperkirakan dan atau angka kumulatif dari kegagalan yang dapat terjadi.

- Metode Deteksi (Detection)

Nilai detection diasosiasikan dengan pengendalian saat ini. Detection adalah pengukuran terhadap kemampuan mengendalikan/mengontrol kegagalan yang dapat terjadi.

\section{- Risk Priority Number (RPN)}

Nilai ini merupakan produk dari hasil perkalian tingkat keparahan, tingkat kejadian, dan tingkat deteksi. RPN menentukan prioritas dari kegagalan. Nilai tersebut digunakan untuk meranking kegagalan proses yang potensial.Nilai RPN dapat ditunjukkan dengan persamaan sebagai berikut:

$\mathrm{RPN}=S \times O \times D$.

\section{Metode Penelitian}

Makalah ini menyajikan langkah-langkah terbaik untuk mempelajari dan menganalisis FMEA untuk penerapan di berbagai industri. Makalah ini juga menginformasikan kegunaan FMEA dalam menganalisa resiko. Studi makalah ini dimulai dengan pengumpulan berbagai paper mulai dari tahun 2015 sampai 2020. Kata kunci dalam pencarian paper yang digunakan adalah "Failure Mode and Effect Analysis".

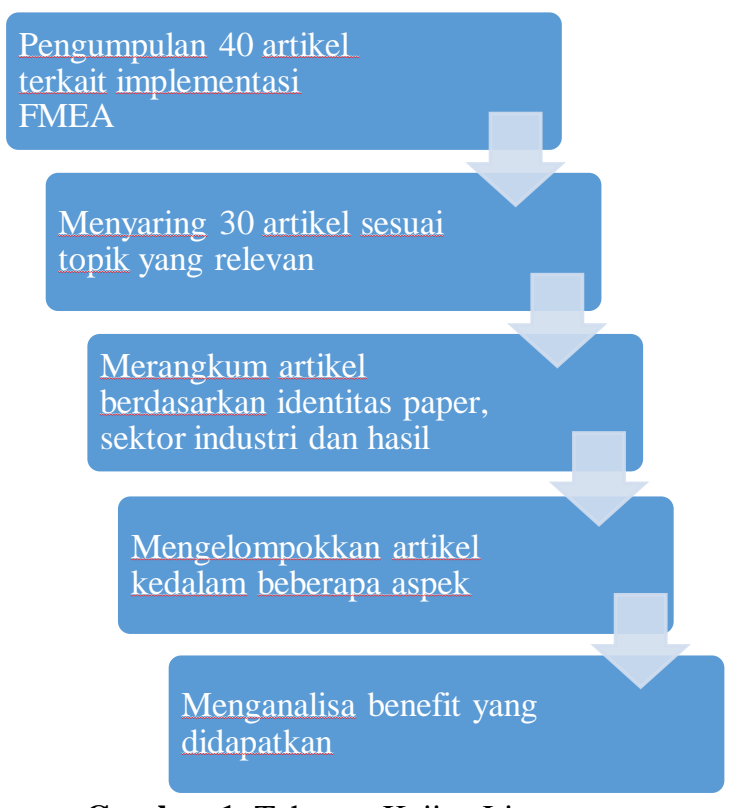

Gambar 1. Tahapan Kajian Literatur

Agar makalah ini tersusun secara spesifik, jelas dan terarah maka perlu dilakukan tahapan yaitu sebagai berikut:

- Langkah pertama: Pengumpulan artikel: Artikel yang berhasil dikumpulkan sebanyak 50 artikel dengan kata kunci Failure Mode and Effect Analysis

- Langkah kedua: Penyaringan: Menyaring dan mapping beberapa artikel menjadi 30 artikel sesuai topik atau tema yang relevan.

- Langkah ketiga: Rangkuman Artikel: Merangkum semua artikel yang relevan bedasarkan identitas artikel, sektor industri dan hasil penelitian.

- Langkah keempat: Fokus beberapa Aspek: Mengelompokkan semua artikel kedalam beberapa aspek yaitu, fokus industri, fokus wilayah publikasi dan fokus tahun publikasi.

- Langkah kelima: Analisis benefit: Menganalisis keuntungan yang didapatkan dari setiap artikel.

Untuk lebih jelas terhadap tahapan literature review pada makalah ini bisa dilihat pada gambar 1

\section{Hasil dan Pembahasan}

Berdasarkan Tabel 1, terlihat bahwa makalah ini merangkum 30 artikel yang berkaitan dengan penerapan Failure Mode And Effects Analysis di berbagai industri dan terangkum berdasarkan identitas artikel, sektor industri dan hasil penelitian yang didapatkan. 
Tabel 1. Kajian Literatur Implementasi FMEA

\begin{tabular}{|c|c|c|c|}
\hline No. & Peneliti & Sektor Industri & Hasil \\
\hline 1 & [2] & Jasa & $\begin{array}{l}\text { Tingkat perhatian dan kepuasan pada item } \\
\text { peningkatan prioritas ketika terjadi kegagalan } \\
\text { layanan bervariasi antara pendapat karyawan } \\
\text { internal dan pelanggan yang berbeda. }\end{array}$ \\
\hline 2 & [3] & Manufaktur & $\begin{array}{l}\text { Mendiagnosis risiko kualitas dan keamanan pangan } \\
\text { dalam rantai makanan dingin }\end{array}$ \\
\hline 3 & [4] & Manufaktur & $\begin{array}{l}\text { Membantu produsen catu daya untuk menilai faktor } \\
\text { risiko dan menentukan mode kegagalan utama. }\end{array}$ \\
\hline 4 & [5] & Kesehatan & $\begin{array}{l}\text { Sebanyak } 67 \text { mode kegagalan diidentifikasi untuk } \\
26 \text { proses perawatan klinis }\end{array}$ \\
\hline 5 & [6] & Industri Oli & $\begin{array}{l}\text { Sistem mikroreaktor relatif lebih aman dari pada } \\
\text { sistem konvensional }\end{array}$ \\
\hline 6 & [7] & Pertambangan & $\begin{array}{l}\text { Nilai RPN tertinggi } 168 \text { untuk mode kegagalan } \\
\text { potensial diperoleh untuk subsistem listrik (SSE) }\end{array}$ \\
\hline 7 & [8] & Manufaktur & $\begin{array}{l}\text { Terdapat } 23 \text { potensi bahaya dalam } 8 \text { proses } \\
\text { produksi, antara lain: penerimaan bahan baku, } \\
\text { penyimpanan, pembuatan adonan, pemanggangan, } \\
\text { penggorengan, pendinginan, pengemasan, } \\
\text { distribusi. }\end{array}$ \\
\hline 8 & [9] & Pertanian & $\begin{array}{l}\text { Nilai RPN tertinggi pada kurangnya ketelitian dan } \\
\text { pelatihan atau penyuluhan pemetik, penanganan } \\
\text { hewan peliharaan dan penyakit, serta faktor usia } \\
\text { pemetik. }\end{array}$ \\
\hline 9 & [10] & Manufaktur & $\begin{array}{l}\text { Kesalahan manusia dapat dikurangi dan kehandalan } \\
\text { peralatan mesin three-in-one dapat ditingkatkan. }\end{array}$ \\
\hline 10 & [11] & Jasa & $\begin{array}{l}\text { Sub-SRCFS yang paling penting termasuk inspeksi } \\
\text { truk yang tidak sesuai, sistem rem yang buruk, dan } \\
\text { kurangnya kekuatan pelindung depan dan belakang } \\
\text { pengangkut. }\end{array}$ \\
\hline 11 & [12] & Konstruksi & $\begin{array}{l}\text { Skala tertinggi dengan nilai } 10 \text { adalah benda } \\
\text { terjatuh pada aktifitas lifting by crane }\end{array}$ \\
\hline No. & Peneliti & Sektor Industri & Hasil \\
\hline 12 & [13] & Konstruksi & $\begin{array}{l}\text { Persediaan yang tinggi merupakan faktor dominan } \\
\text { yang harus dikendalikan oleh perusahaan untuk } \\
\text { mencegah risiko kegagalan proses di gudang }\end{array}$ \\
\hline 13 & [14] & Manufaktur & $\begin{array}{l}\text { Angka tertinggi pada kegagalan yang terkait dengan } \\
\text { pemangkasan kain pada tenter }\end{array}$ \\
\hline
\end{tabular}




\begin{tabular}{|c|c|c|c|}
\hline 14 & {$[15]$} & Manufaktur & $\begin{array}{l}\text { Body plate merupakan komponen yang memiliki } \\
\text { potensi bahaya utama pada mesin evaporator. }\end{array}$ \\
\hline 15 & [16] & Konstruksi & $\begin{array}{l}\text { Kriteria longsoran karena kurangnya penopang } \\
\text { yang tepat dianggap sebagai risiko besar }\end{array}$ \\
\hline 16 & [17] & Konstruksi & $\begin{array}{l}\text { Tiga indikator tertinggi adalah perencanaan, } \\
\text { kontrak kerja dan kegiatan workshop }\end{array}$ \\
\hline 17 & {$[18]$} & Petrokimia & $\begin{array}{l}\text { Kesulitan dalam memprioritaskan RPN dalam } \\
\text { kasus sistem yang kompleks seperti penyimpanan } \\
\text { LNG telah diatasi }\end{array}$ \\
\hline 18 & [19] & Manufaktur & $\begin{array}{l}\text { Peringkat risiko menurut ekstensi ini dibandingkan } \\
\text { dengan FMEA tradisional, mengarah pada prioritas } \\
\text { yang lebih handal dan meyakinkan. }\end{array}$ \\
\hline 19 & [20] & Jasa & $\begin{array}{l}\text { Hasil penelitian diperoleh } 7 \text { dari } 18 \text { jenis risiko yang } \\
\text { memiliki prioritas tinggi untuk diperbaiki. }\end{array}$ \\
\hline 20 & {$[21]$} & Jasa & $\begin{array}{l}\text { Hasil studi ini akan membantu manajemen dan staf } \\
\text { SPBU mencegah risiko keselamatan. }\end{array}$ \\
\hline 21 & [22] & Manufaktur & $\begin{array}{l}\text { Mencegah asal muasal cacat produk dari proses } \\
\text { pembuatannya. }\end{array}$ \\
\hline 22 & {$[23]$} & Manufaktur & $\begin{array}{l}\text { Didapatkan } 3 \text { pekerjaan dengan tingkat kecelakaan } \\
\text { paling tinggi, yaitu pekerjaan menggunakan mesin } \\
\text { saw blade, pekerjaan menggunakan mesin las dan } \\
\text { pekerjaan menggunakan mesin bor. }\end{array}$ \\
\hline 23 & [24] & Konstruksi & $\begin{array}{l}\text { Empat poin penyebab cacat pasir besi yang paling } \\
\text { dominan (kegiatan penambangan, penerimaan, } \\
\text { pemeriksaan dan pengiriman) }\end{array}$ \\
\hline 24 & [25] & Industri Oli & $\begin{array}{l}\text { Kemungkinan bahaya dalam unit ini sebelum dan } \\
\text { sesudah tindakan intervensi masing-masing adalah } \\
4,5 \text { dan } 3,25 \text { dan tingkat keparahan tertinggi terkait } \\
\text { dengan produksi perkakas }\end{array}$ \\
\hline 25 & [26] & Kesehatan & $\begin{array}{l}\text { Mode kegagalan dalam fase sterilisasi sebagian } \\
\text { besar disebabkan oleh faktor manusia (operator) }\end{array}$ \\
\hline 26 & {$[27]$} & $\begin{array}{l}\text { Industri kecil } \\
\text { dan menengah }\end{array}$ & $\begin{array}{l}\text { Mengurangi penolakan kualitas sekitar } 3 \% \text { menjadi } \\
4 \% \text { di perusahaan }\end{array}$ \\
\hline No. & Peneliti & Sektor Industri & Hasil \\
\hline 27 & {$[28]$} & Jasa & $\begin{array}{l}\text { Pengambilan keputusan yang lebih baik terkait } \\
\text { inspeksi dan pemeliharaan, yang membuat } \\
\text { pengiriman kapal tanker lebih aman dan andal. }\end{array}$ \\
\hline 28 & [29] & Jasa & $\begin{array}{l}\text { Cacat lini produksi dapat diselesaikan dengan lebih } \\
\text { cepat dan lebih efektif. }\end{array}$ \\
\hline 29 & [30] & Industri pupuk & $\begin{array}{l}\text { Resiko tertinggi pada proses pengelasan terutama } \\
\text { yang bekerja di ketinggian. }\end{array}$ \\
\hline
\end{tabular}




\begin{tabular}{|l|l|l|l|}
\hline 30 & {$[31]$} & Manufaktur & $\begin{array}{l}\text { Model perbaikan untuk mengevaluasi kekritisan } \\
\text { mode limbah pemeliharaan }\end{array}$ \\
\hline
\end{tabular}

Pada makalah ini, artikel FMEA yang paling dominan diimplementasikan di industri manufaktur (Gambar 2) yang ditelusuri dari publikasi mulai tahun 2015 sampai 2020 (Gambar 3).

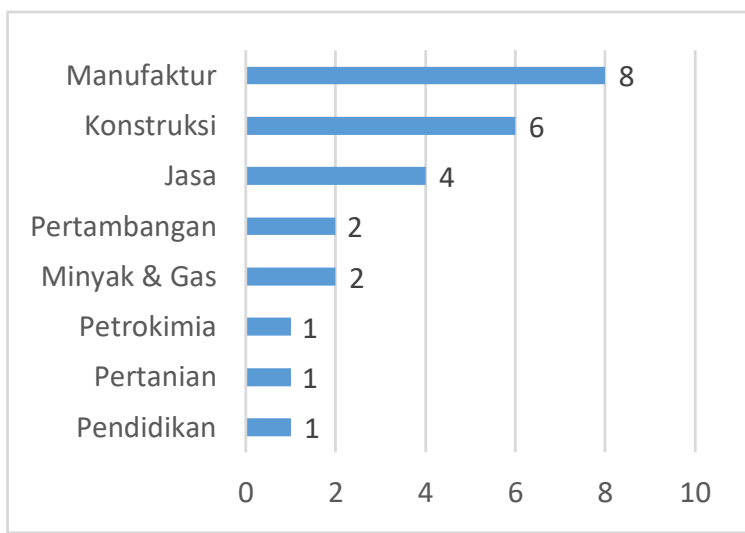

Gambar 2. Fokus instansi

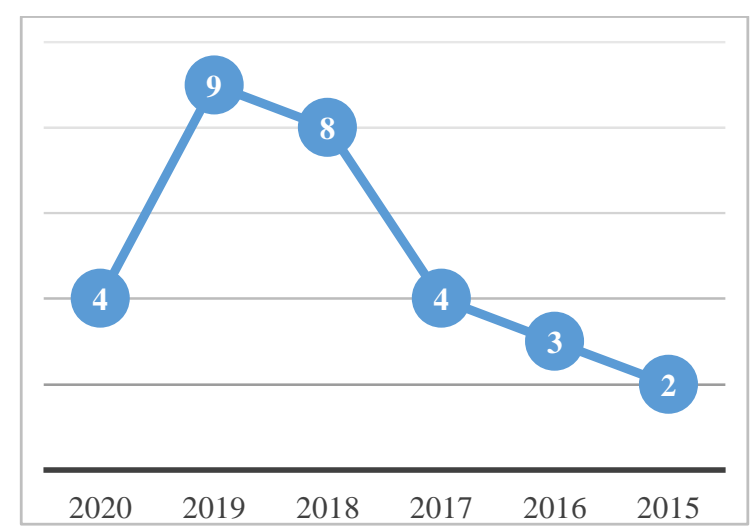

Gambar 3. Fokus tahun publikasi

FMEA dianggap sebagai teknik untuk menganalisis suatu kegagalan, mengindentifikasi penyebab kegagalan terbesar dan mengeliminasinya, mengurangi peluang terjadinya kegagalan dan membangun kualitas dari produk dan proses. Keberhasilan FMEA di berbagai sektor industri telah mendapat keuntungan yang signifikan setelah menerapkan teknik tersebut.

Ketika diterapkan di industri Manufaktur, FMEA dapat mengidentifikasi penyebab kecelakaan kerja pada mesin evaporator [15], menentukan prioritas kecelakaan kerja pada mesin saw blade [23], menentukan model perbaikan untuk mengevaluasi kekritisan mode limbah pemeliharaan. Ketika diterapkan di sektor konstruksi, FMEA dapat menaganalisis risiko kritis tertinggi dalam proyek yaitu perencanaan, kegiatan di workshop dan kegiatan paska proyek [17]. Ketika diterapkan di sektor jasa, FMEA dapat memprioritaskan keputusan terkait pengecekan, pemeliharaan dan perbaikan komponen/alat secara rutin dan terencana serta pergantian jika sudah tidak layak pakai [32], meningkatkan kepuasan pelanggan [2] dan membantu manajemen dalam mencegah risiko keselamatan [21].

Saat penerapan alat FMEA pada sektor industri, sering diintegrasikan dengan berbagai macam metode pemecahan masalah guna mendapatkan prioritas perbaikan seperti Fuzzy [7] [11] [14] [18] [20], Job Safety Analysis [23], Hazop [6], Fault Tree Analysis [14], Analytical Hierarchy Process [31], DEMATEL [29], Metode Kano [2] dan Mode Assessment Model [4]

Makalah ini juga mengidentifikasi sebaran publikasi implementasi FMEA di berbagai sektor industri di kawasan Asia berdasarkan wilayah yang teridentifikasi (Gambar 4). Makalah ini, Indonesia merupakan pemasok terbesar jumlah publikasi dengan 10 artikel diikuti Taiwan 5 artikel, Iran 4 artikel, China 3 artikel, Malaysia dan Turki masing-masing 2 artikel dan Thailand 1 artikel

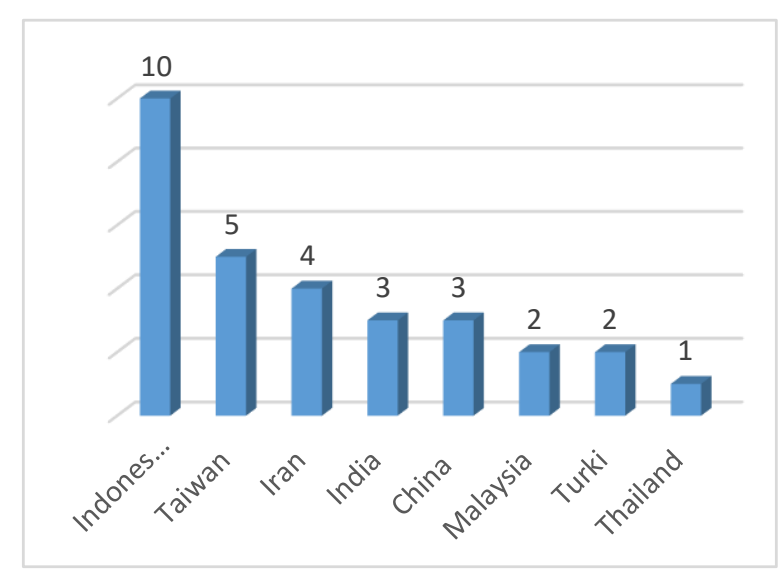

Gambar 4. Fokus wilayah publikasi 


\section{Gaps dan pengembangan FMEA di berbagai industri kawasan Asia}

Saat ini, implementasi FMEA dikawasan Asia didominasi oleh industri manufaktur, konstruksi dan jasa. Saat ini juga negara-negara di kawasan Asia sedang mengalami pertumbuhan industri yang cukup pesat termasuk diantaranya Indonesia, India, China dll. Oleh karena itu penting untuk menerapkan alat FMEA guna menganalisa resiko kegagalan baik jangka pendek maupun jangka panjang pada masing-masing sektor industri. FMEA merupakan metode yang cocok untuk analisa mode kegagalan dan efek yang ditimbulkan. Alat ini juga dapat dipadukan dengan metode lain sehingga dapat menghasilkan keuntungan yang lebih komplek. Metode yang paling banyak digunakan adalah perhitungan RPN, manajemen risiko, manajemen kualitas, mode fuzzy dan pemeliharaan. Untuk penelitian selanjutnya implementasi FMEA dapat dikembangkan dengan menggunakan pendekatan statistik. Statistik FMEA bertujuan untuk mengetahui hubungan antara indikator dan variabel kejadian, keparahan dan deteksi. Serta hubungan antara variabel kejadian, keparahan dan deteksi dengan RPN. Tindakan yang diambil akan didasarkan pada indikator yang memiliki angka lebih tinggi untuk diprioritaskan. Pendekatan statistik ini dapat menggunakan Structural Equation Modeling (SEM) dengan banyak menggunakan software statistik seperti Smart PLS, Amos, Lisrel, IBM Statistik dll. Untuk model kausalitas antara Severity, Occurance dan Detection dan RPN dapat dilihat pada Gambar 5.

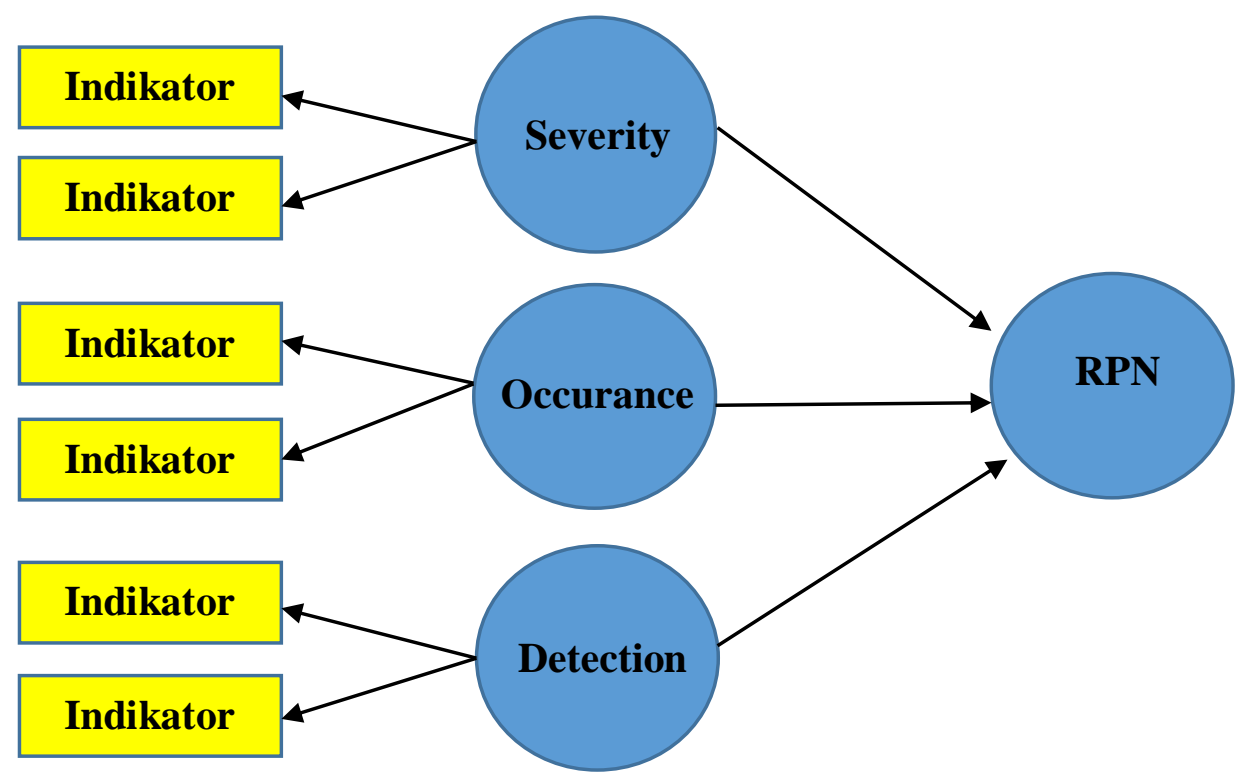

Gambar 5. Statistik FMEA untuk penelitian selanjutnya

\section{Kesimpulan dan Saran}

Makalah ini mendukung akademisi dan praktisi dalam mengimplementasikan alat FMEA baiak secara efektif maupun secara proaktif untuk mengurangi risiko kegagalan dan memberikan wawasan lebih tentang mutakhirnya. Fokus utama metode FMEA dalam suatu permasalahan adalah mencegah terjadinya kegagalan dan efek yang ditimbulkan. Dengan kata lain, FMEA dengan mengoptimalkan proses dan produk membantu mengurangi biaya yang besar. Pengurangan biaya dapat dilakukan pada tahap awal pengembangan proses dan perubahan relatif sederhana dengan biaya rendah. Selain itu keuntungan yang dapat diperoleh dari penerapan FMEA diantaranya meningkatan keamanan, kualitas produk, kehandalan mesin, nama baik perusahaan, kepuasan konsumen, dan adanya catat historis dari peristiwa kegagalan.

Saran dalam makalah ini lebih baik penelitian pada masa depan, menerapkan FMEA dengan berfokus pada pengembangan 
dengan menggunakan pendekatan statistik SEM (Stuctural Equation Modeling)

\section{Daftar Pustaka}

[1] D. H. Stamatis, Failure Mode and Effect Analysis FMEA from Theory to Execution. Wisconsin: ASQC Quality Press, 1995.

[2] L. L. Tang, S. H. Chen, and C. C. Lin, "Integrating fmea and the Kano model to improve the service quality of logistics centers," Processes, vol. 9, no. 1, pp. 116, 2020, doi: 10.3390/pr9010051.

[3] J.-Y. Wu and H.-I. Hsiao, "Food quality and safety risk diagnosis in the food cold chain through failure mode and effect analysis," Food Control, p. 107501, 2020 , doi:

10.1016/j.foodcont.2020.107501.

[4] J. J. H. Liou, P. C. Y. Liu, and H. W. Lo, "A failure mode assessment model based on neutrosophic logic for switched-mode power supply risk analysis," Mathematics, vol. 8, no. 12, pp. 1-19, 2020, doi: 10.3390/math8122145.

[5] L. Moradi, A. Emami Sigaroudi, M. Pourshaikhian, and M. Heidari, "Risk Assessment of Clinical Care in Emergency Departments ByHealth Failure Modes and Effects Analysis," $J$. Holist. Nurs. Midwifery, vol. 30, no. 1, pp. 35-44, 2020, doi: 10.32598/jhnm.30.1.6.

[6] N. Akkarawatkhoosith, A. Srichai, A. Kaewchada, C. Ngamcharussrivichai, and A. Jaree, "Evaluation on safety and energy requirement of biodiesel production: Conventional system and microreactors," Process Saf. Environ. Prot., vol. 132, pp. 294-302, 2019, doi: 10.1016/j.psep.2019.10.018.

[7] J. Balaraju, M. Govinda Raj, and C. S. Murthy, "Fuzzy-FMEA risk evaluation approach for LHD machine-A case study," J. Sustain. Min., vol. 18, no. 4, pp. 257-268, 2019, doi: 10.1016/j.jsm.2019.08.002.
[8] R. F. Ramadhan and M. Evi Widowati, "Failure Mode and Effect Analysis (FMEA) Application for Safety Risk Assessment Design of ' $\mathrm{X}$ ' Bakery," Unnes J. Public Heal., vol. 3, no. 1, pp. $1-10$, 2019 , doi:10.15294/ujph.v8i1.22534.

[9] I. B. Suryaningrat, W. Febriyanti, and W. Amilia, "Identifikasi Risiko Pada Okra Menggunakan Failure Mode and Effect Analysis (Fmea) Di Pt. Mitratani Dua Tujuh Di Kabupaten Jember," $J$. Agroteknologi, vol. 13, no. 01, p. 25, 2019, doi: 10.19184/j-agt.v13i01.8265.

[10] X. S. Zhao and M. J. J. Wang, “Applying an improved failure mode effect analysis method to evaluate the safety of a three - in - one machine tool," no. September 2018, 2019, doi: 10.1002/hfm.20823.

[11] S. Ghaleh, M. Omidvari, P. Nassiri, M. Momeni, and S. Mohammadreza Miri Lavasani, "Pattern of safety risk assessment in road fleet transportation of hazardous materials (oil materials)," Saf. Sci., vol. 116, no. May 2018, pp. 112, 2019, doi: $10.1016 /$ j.ssci.2019.02.039

[12] F. Fatullah, "Menggunakan Metode FMEA (Failure Mode And Effect Analysis) - (Studi Kasus : Proyek ORF Bukit Tua di PT. Raga Perkasa Ekaguna, Madura Tahun 2018)," Semin. Nas. Inov. Teknol. - SNITek 2019, pp. 234 244, 2019.

[13] A. Hassan, "Fuzzy-analytical-hierarchy process in failure mode and e ff ect analysis ( FMEA ) to identify process failure in the warehouse of a cement industry," pp. 378-388, 2019, doi: 10.1108/JEDT-05-2019-0131.

[14] N. G. Mutlu and S. Altuntas, "Risk analysis for occupational safety and health in the textile industry: Integration of FMEA, FTA, and BIFPET methods," Int. J. Ind. Ergon., vol. 72, no. May, pp. 222-240, 2019, doi: 10.1016/j.ergon.2019.05.013.

[15] M. R. Akbar, A. Subekti, and M. R. Dhani, "Identifikasi Bahaya Dengan 
Menggunakan Metode Fmea Pada Mesin Evaporator Di Pabrik Gula," Proceeding 2nd Conf. Saf. Eng. Its Appl., vol. 2, no. 1, pp. 779-782, 2018, doi:http://journal.ppns.ac.id/index.php/s eminarK3PPNS/article/view/803.

[16] E. Ilbahar, A. Karaşan, S. Cebi, and C. Kahraman, "A novel approach to risk assessment for occupational health and safety using Pythagorean fuzzy AHP \& fuzzy inference system," Saf. Sci., vol. 103, no. October 2017, pp. 124-136, 2018, doi: 10.1016/j.ssci.2017.10.025.

[17] A. Z. Muttaqin and Y. A. Kusuma, "Analisis Failure Mode And Effect Analysis Proyek X Di Kota Madiun," JATI UNIK J. Ilm. Tek. dan Manaj. Ind., vol. 1, no. 1, p. 72, 2018, doi: 10.30737/jatiunik.v1i2.118.

[18] V. R. Renjith, M. Jose kalathil, P. H. Kumar, and D. Madhavan, "Fuzzy FMECA (failure mode effect and criticality analysis) of LNG storage facility," J. Loss Prev. Process Ind., pp. 537-547, 2018, doi: 10.1016/j.jlp.2018.01.002.

[19] S. Yousefi, A. Alizadeh, J. Hayati, and M. Baghery, "HSE risk prioritization using robust DEA-FMEA approach with undesirable outputs: A study of automotive parts industry in Iran," Saf. Sci., vol. 102, no. September 2017, pp. 144-158, 2018, doi: 10.1016/j.ssci.2017.10.015.

[20] T. Immawan, W. Sutrisno, and A. K. Rachman, "Operational risk analysis with Fuzzy FMEA ( Failure Mode and Effect Analysis ) approach ( Case study : Optimus Creative Bandung )," MATEC Web Conf., vol. 01084, 2018, doi: https://doi.org/10.1051/matecconf/2018 15401084.

[21] Y. Liu, Z. Kong, and Q. Zhang, "Ecotoxicology and Environmental Safety Failure modes and e ff ects analysis ( FMEA) for the security of the supply chain system of the gas station in China," Ecotoxicol. Environ. Saf., vol. 164, no. 5, pp. 325-330, 2018, doi: 10.1016/j.ecoenv.2018.08.028.
[22] E. F. Ramly and H. Atan, "Case study on development of process failure mode effect analysis (PFMEA) - Issues and recommendation," Proc. Int. Conf. Ind. Eng. Oper. Manag., vol. 2018-March, no. 2003, pp. 344-350, 2018, doi: http://ieomsociety.org/ieom2018/procee dings/.

[23] A. Levi, "Usulan Perbaikan Keselamatan Kerja Menggunakan Metode Job Safety Analysis (Jsa) Dan Failure Mode and Effect Analysis (Fmea)," Spektrum Ind., vol. 15, no. 2, p. 151, 2017, doi: 10.12928/si.v15i2.7549.

[24] V. N. Helia and W. N. Wijaya, "Failure Mode and Effect Analysis ( FMEA ) Applications to Identify Iron Sand Reject and Losses in Cement Industry: A Case Study," IOP Conf. Ser. Mater. Sci. Eng., 2017, doi: 10.1088/1757899X/215/1/012039.

[25] M. Kolahdouzi, H. H. Gholam, N. A. Ebrahim, R. A. S. Maryam, and Y. avan Mohsen, "Use of failure mode and effects analysis in improving the safety of i.v. drug administration," Am. J. Heal. Pharm., vol. 62, no. 9, pp. 917-920, 2017, doi: 10.1093/ajhp/62.9.917.

[26] Y. Chen and P. Tsai, "Evaluating the operational risks of biomedical waste using failure mode and effects analysis," no. $151, \quad 2017, \quad$ doi: $10.1177 / 0734242 X 17700717$.

[27] J. Doshi and D. Desai, "Application of Failure Mode \& Effect Analysis (FMEA) for Continuous Quality Improvement - Multiple Case Studies in Automobile," Int. J. Qual. Res., vol. 11, no. 2, pp. 345-360, 2016, doi: 10.18421/IJQR11.02-07.

[28] Q. Zhou and V. V Thai, "Fuzzy and grey theories in failure mode and effect analysis for tanker equipment failure prediction," Saf. Sci., vol. 83, pp. 74-79, 2016, doi: 10.1016/j.ssci.2015.11.013.

[29] Y. Lee, W. Chu, Q. Chen, S. Tsai, J. 
Wang, and W. Dong, "Integrating decision-making trial and evaluation laboratory model and failure mode and effect analysis to determine the priority in solving production problems," vol. 8, no. 4, pp. 1-12, 2016, doi: $10.1177 / 1687814016641011$.

[30] M. Kangavari, S. Salimi, R. Nourian, L. Omidi, and A. Askarian, "An application of failure mode and effect analysis (FMEA) to assess risks in petrochemical industry in Iran," Iran. J. Heal. Saf. Environ., vol. 2, no. 2, pp. 257-263, 2015, doi: https://doaj.org/article/4749450470aa4e 37815 acd9de30c6dd9.

[31] A. Sutrisno, I. Gunawan, and S. Tangkuman, "Modified failure mode and effect analysis ( FMEA ) model for accessing the risk of maintenance waste," Procedia Manuf., vol. 4, no. Iess, pp. 23-29, 2015, doi: 10.1016/j.promfg.2015.11.010. 